\title{
UN VAGABUNDO EN LA SELVA. EL CASO DE JUAN DE SOSA
}

\author{
Ana Luisa IZquierdo y de LA CUEVA \\ Centro de Estudios Mayas
}

Guillermo BERNAL ROMERo Escuela Nacional de Antropología e Historia

... que ahí en esos pueblos [de Yucatán] pues en lugar de amanecer [los indígenas] dando gracias a su Creador por los beneficios de su Magnánima Mano recibidos, amanecen unos por el monte, otros desesperados, otros ahorcándose, abrumados ya con tantas y tan exhorbitantes cargas ...

(AGN, México, v. 497, Sermón del presbítero Nicolás Gregorio de Carrión, 1679)

\section{Estudio introductorio}

La reconstrucción del pasado prehispánico y colonial de los pueblos mayas tiene múltiples caminos; uno de los poco explorados es la consulta de documentos existentes en archivos nacionales y extranjeros.

Fue, precisamente, al buscar información inédita sobre los mayas que encontramos en el ramo de Inquisición del Archivo General de la Nación el documento que ahora presentamos: se trata del legajo titulado: "Autos que remite el Comisario de Campeche contra Juan de la Sosa, natural del puerto de Campeche". 1

El legajo contiene una causa judicial que las autoridades civiles de la Gobernación de Yucatán llevaron a cabo en 1679 contra un criollo: Juan de la Sosa —o Juan de Sosa o de las Sosas, de acuerdo con las diversas formas que muestra el documento-, el cual fue procesado a causa de haber penetrado y permanecido durante varios meses en la zona de las "Las Montañas".

${ }^{1}$ AGN, ramo de Inquisición, vol. 639, exp. 7, fojas 264-278, "Autos que remite el Comisario de Campeche contra Juan de la Sosa natural del puerto de Campeche". Mérida, 1679.

${ }^{2}$ El nombre de "Las Montañas" lo usaron Scholes y Roys en su libro sobre los 
Esta región estuvo situada al sur de la península yucateca y fue habitada por indígenas fugitivos de la Gobernación, así como por grupos mayas independientes asentados ahí desde la época prehispánica, como los cehaches y los itzaes.

Estos pueblos, llamados en ese entonces, cimarrones o "montaraces" permanecieron apegados a sus antiguas formas de vida y creencias religiosas, a pesar de las actividades misioneras realizadas en esa región entre 1603 y 1670 , que intentaron someterlos pacíficamente por medio de la evangelización. ${ }^{3}$

La zona de "Las Montañas" se mantuvo fuera del dominio español, oficialmente, hasta fines del siglo xvII, razón por la cual estaba vedado acceder a ella, prohibición que De la Sosa no acató.

El proceso contra Juan de la Sosa contiene aportaciones historiográficas, pues nos permite conocer ritos y dioses venerados por los mayas de "Las Montañas", así como referencias sobre las actividades militares que la Gobernación llevó a cabo en 1679 con el fin de someter a los asentamientos "cimarrones".

En síntesis, los hechos referidos por el documento se desarrollaron de la manera que narramos a continuación. A principios de 1679, Juan de la Sosa, criollo, natural de Campeche, soltero y de unos 25 años de edad, se desempeñaba como vaquero en la estancia ganadera de Nohakal [Nohak'al], ${ }^{4}$ cercana al puerto de Campeche.

$\mathrm{Al}$ aproximarse la Cuaresma (febrero o marzo), De la Sosa abandonó la estancia y se dirigí́ a "Las Montañas" en compañía de dos indígenas, uno llamado Antón Habnal [Haabnal], ${ }^{5}$ de oficio noriero, originario de [Pokyaxum], ${ }^{6}$ y otro de apellido K'u (a veces lo llama Antón K'u) ${ }^{7}$ y del que se señaló había vivido antes en esa región. De la Sosa afirmó, inicialmente, que el motivo de su salida fue por aversión a las confesiones de la Cuaresma; después sostuvo que lo hizo porque estaba cansado de trabajar y que los indios lo engañaron diciéndole que sólo irían de cacería.

chontales de Acalán para incluir en él toda el área donde vivían los indios insumisos del sur de Campeche, Quintana Roo y el norte del Petén, pero ellos lo tomaron de López de Cogolludo, del libro 8, capítulo 8 de su Historia. Cf. nota 3.

${ }^{3}$ France Scholes y Ralph Roys, The Maya Chontal of Acalan Tixchel: A Contribution to the History and Ethnology of the Yucatan Peninsula, University of Oklahoma Press, Oklahoma, 1968, cap. xI.

${ }^{4}$ La traducción de estos términos se debe a Jorge Cocom Pech y a María Luisa Góngora Pacheco: "Gran aguada".

s"Año elote".

6 "Pelota de pájaro verde" puede referirse al quetzal.

7 "Dios". 
En el trayecto hacia "Las Montañas" pasaron por Tixmucuy, [Tix mukuy], ${ }^{8}$ Bolonchén [Bolonch'en] ${ }^{9}$ de Cauich [Ka'wich] ${ }^{10}$ y llegaron a Sahcabchén [Sahkabc'een], ${ }^{11}$ último pueblo de la Gobernación (véase mapa). De ahí "tomaron un camino ancho" que los llevó al interior de "Las Montañas", deteniéndose en un paraje llamado Pech Max [Pech' Maax], ${ }^{12}$ donde vivían "nueve indios de armas", "seis indias" y "cuatro niños". ${ }^{13}$

De la Sosa participó en los rituales que habitualmente se desarrollaron en ese sitio, sobre ellos hablaremos detenidamente, más adelante.

Transcurridas seis semanas en Pech Max, De la Sosa y los indios prosiguieron su viaje por "Las Montañas". En el curso de una noche, uno de los indígenas se separó; días después, al escuchar un disparo, De la Sosa y el indio restante corrieron por rumbos distintos. Desorientado, el criollo buscó una vía de retorno a la Gobernación; al cabo de cuatro días llegó a una aldea de indios insumisos llamada Halalmis, ${ }^{14}$ que estaba abandonada y cubierta por la vegetación. De Halalmis tomó una vereda y dos días después se encontró con Luis Che ${ }^{15}$ y otros indígenas de Bekal [Beechal] ${ }^{16}$ que se dirigían a Cauich [Ka'wich], otro pueblo fronterizo de la Gobernación (véase mapa), después de haber colectado cera en algún sitio de "Las Montañas". En su segunda declaración, De la Sosa precisó que el encuentro tuvo lugar en un paraje llamado Yakab [Yak'ab Balam]. ${ }^{17}$ Conducido por los indígenas, el criollo arribó a Cauich [Ka'wich] tras nueve días de viaje.

El 9 de septiembre de 1679, Martín de Rebolledo (quien, al parecer, tenía algún cargo en Cauich [Ka'wich], que el documento no precisa) tomó conocimiento de la presencia de De la Sosa y ordenó al teniente Esteban Tzuc que lo aprehendiese; llevado ante Rebolledo, él lo interrogó por medio de un intérprete, ya que se expresaba torpemente en español y en cambio lo hacía fluidamente en lengua maya; en esta audiencia refirió sus andanzas por la región. Enseguida interrogó a Luis Che, quien le confirmó haber traído al criollo de "Las Montañas"; también le

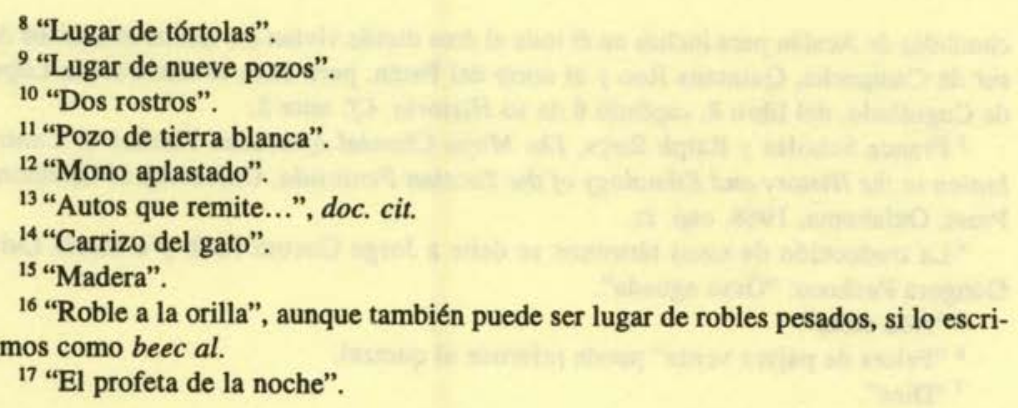




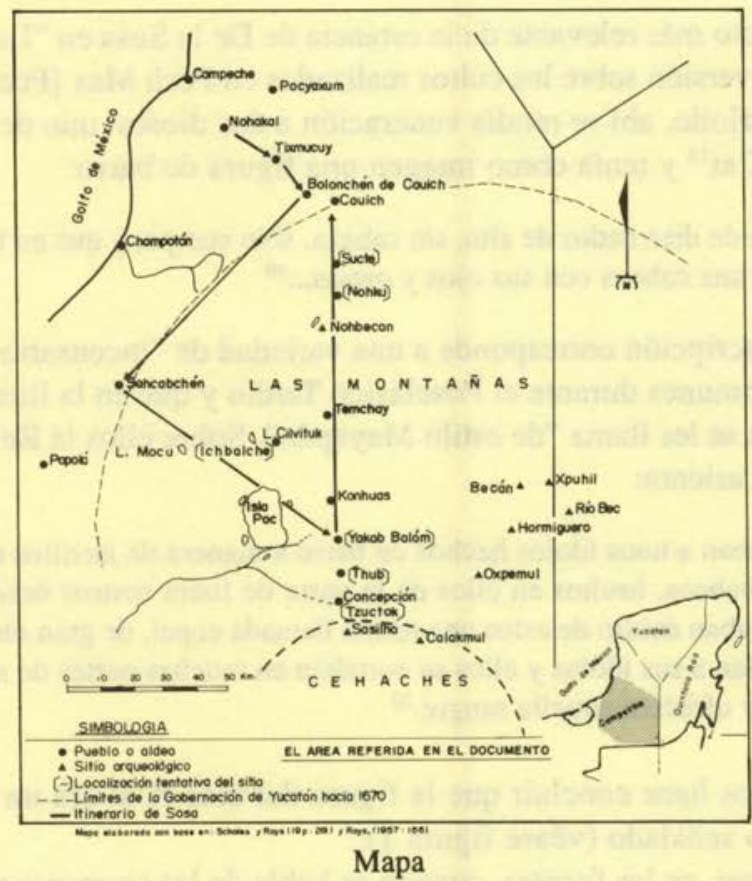

explicó que para ir a esa zona había obtenido el permiso del capitán Juan de Solís, con quien se había entrevistado en la villa de Campeche.

Rebolledo llevó a De la Sosa al pueblo de Hopelchén [Hop' elch'een] y de ahí lo envió a Mérida junto con una carta para el Gobernador en la que le informaba sobre el caso.

El viaje de De la Sosa a territorio montaraz puede reconstruirse con precisión hasta Sahcabchén [Sahkabch'een], pueblo sur oriental de la Gobernación que durante el siglo xviI se constituyó como límite y frontera con la región de "Las Montañas". Los parajes de Pech Max [Pech Maax], Halalmis y Yakab [Yak'ab Balam] no pudieron ser localizados porque no aparecen mencionados en los informes y crónicas de los militares ni de los misioneros que recorrieron la zona durante esa centuria. La única referencia es acerca de Yakab Balam [Yak'ab Balam], que estaba a nueve días de camino de Cauich [Ka'wich]. Ello sólo nos permite suponer que de la Sosa se adentró mucho en "Las Montañas", pues los viajes en esa zona solían cubrir distancias de entre 12 y 13 kilometros por día, por lo tanto debió estar situado a unos 100 kilómetros al sur de Cauich [Ka'wich], en algún punto de las selvas del sur de Campeche o suroeste de Quintana Roo. 
El aspecto más relevante de la estancia de De la Sosa en "Las Montañas" es su versión sobre los cultos realizados en Pech Max [Pech'Maax]. Según el criollo, ahí se rendía veneración a dos dioses: uno de ellos era llamado $\mathrm{K}^{\prime}$ at $^{18}$ y tenía como imagen una figura de barro:

como de diez dedos de alto, sin cabeza, sólo cuerpo, y que en los pechos tenía una cabeza con sus ojos y orejas... ${ }^{19}$

Esta descripción corresponde a una variedad de "incensarios-ídolos" bastante comunes durante el Posclásico Tardío y que en la literatura arqueológica se les llama "de estilo Mayapán". Sobre ellos la Relación de Valladolid asienta:

adoraban a unos ídolos hechos de barro a manera de jarrillos de maceta de albahaca, hechos en ellos de la parte de fuera rostros desemejados; quemaban dentro de estos una resina llamada copal, de gran olor. Esto le ofrecían a sus ídolos y ellos se cortaban en muchas partes de sus miembros y ofrecían aquella sangre. ${ }^{20}$

Esta cita nos hace concluir que la figura del dios K'at era un incensario del tipo señalado (véase figura 1).

Al parecer, en las fuentes, cuando se habla de las creencias prehispánicas, no existen alusiones al dios $\mathrm{K}$ 'at. En cambio la etnografía sí nos da testimonios sobre su existencia. En la década de los veintes, del presente siglo, Pacheco registró entre los mayas de Quintana Roo la creencia en $\mathbf{K}$ 'at, como un pequeño y travieso ser sobrenatural descrito como un "gnomo" o muñeco de barro ${ }^{21}$ según dicho autor, para algunos indígenas K'at tenía la misión de proteger a los extraviados en el bosque, mientras que para otros era un ser malévolo al servicio de los hechiceros.

En otras regiones de la península el K'at es mejor conocido bajo el nombre de Alux; los yucatecos actuales creen que los Aluxoob son los incensarios de barro antiguos que de noche cobran vida y rondan por el bosque. ${ }^{22}$ El Diccionario Cordemex define a K' at como "un enano mi-

18 "Ídolo".

${ }^{19}$ Ibidem.

${ }^{20}$ Mercedes de la Garza et al., Relaciones histórico-geográficas de la Gobernación de Yucatán, 2 vols., Centro de Estudios Mayas, unaM, México, 1983 (Fuentes para el Estudio de la Cultura Maya, 1), vol. II, p. 39.

${ }^{21}$ Santiago Pacheco Cruz, Usos, costumbres, religión i supersticiones de los mayas, edición privada, Mérida, 1960.

${ }^{22}$ E. Wyllys Andrews, "An Ethnological Note from Cilvituk, Southern Campeche”, 
Figura 1

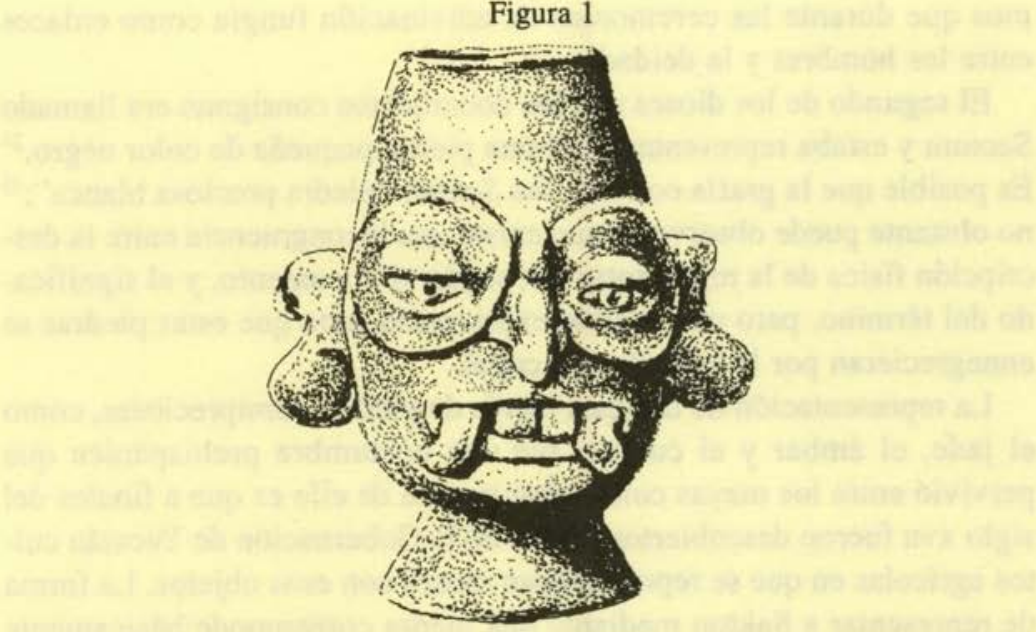

Fuente: Robert Smith Eliot, The Pottery of Mayapan. Including Studies of Ceramic Material from Uxmal, Kabah and Chichen Itza, Peabody Museum of Archaeology and Ethnology, Harvard University, Cambridge, Massachusetts, 1976, p. 251.

tológico que cumple las mismas funciones que el alux"; según Barrera Vásquez, K'at y Alux son dos nombres del ser mitológico que Brinton registró en el siglo XIX como "ah lox kat", "las fuertes imágenes de barro", ${ }^{23}$ y que por las transformaciones de la lengua maya por la influencia del español quedó como Alux.

Las consideraciones anteriores nos dan la certeza de que en el culto montaraz K'at era representado por un incensario del tipo señalado. No obstante, a diferencia de la creencia actual, en dicho culto, $\mathrm{K}$ 'at no era considerado un ser mitológico, sino una deidad; pues se le daba el título de Dios Padre. Como lo podemos recordar, De la Sosa hizo su declaración en lengua indígena, por lo que la expresión, "Dios Padre" fue una traducción de Yum K'u, el vocablo correspondiente en maya yucateco al dios "C". Los epigrafistas aceptan que T1016, el glifo del dios "C", tiene el valor fonético K'u, 'dios' o 'divino'. Llama la atención que ambas lecturas coincidan con el título que según De la Sosa se le confería a K'at: Dios Padre o Yum K'u. Más aún, podemos suponer que el apellido del sacerdote Antón K'u le permitía, de alguna manera, honrar, identificar o consustanciarse con el dios $\mathrm{K}$ 'at, sobre todo si considera-

en Notes on Middle American Archaeology, vol. I, núm. 5, Carnegie Institution of Washington, Historial Research, Washington, 1941, p. 23.

${ }^{23}$ Daniel Brinton, El folklore de Yucatán, Ediciones del Museo Arqueológico e Histórico de Yucatán, Mérida, s.f., pp. 24, 37. 
mos que durante las ceremonias de adivinación fungía como enlaces entre los hombres y la deidad.

El segundo de los dioses que los documentos consignan era llamado Sactum y estaba representado por una piedra pequeña de color negro. ${ }^{24}$ Es posible que la grafía correcta sea Saktun "piedra preciosa blanca"; 25 no obstante puede observarse que existe una incongruencia entre la descripción física de la representación, según el documento, y el significado del término, pero una posible explicación sería que estas piedras se ennegrecieran por la ignición del copal.

La representación de dioses a través de piedras semipreciosas, como el jade, el ámbar y el cuarzo, fue una costumbre prehispánica que pervivió entre los mayas coloniales; prueba de ello es que a finales del siglo XVII fueron descubiertos dentro de la Gobernación de Yucatán cultos agrícolas en que se representaban dioses con esos objetos. La forma de representar a Saktun mediante una piedra corresponde básicamente a la tradición ritual de los lacandones, pero De la Sosa no dio detalles acerca de los atributos de tal deidad.

Según el procesado, las representaciones de K'at y Saktun eran colocadas en el suelo y se encendían candelillas delante de ellas; los celebrantes bailaban alrededor de las imágenes al tiempo que ingerían balché; fungía como sacerdote de la ceremonia el indígena Antón K'u. El criollo añadió que en el culto los indígenas expresaban preguntas acerca de acontecimientos futuros que los perjudicasen. Los cuestionamientos eran dirigidos a Antón K'u, quien se reclinaba sobre la figura de $\mathrm{K}$ 'at, como consultándoselos; después de ello daba las respuestas. Sosa asentó que ninguno de los pronósticos se cumplió, a excepción de uno que predijo la caída de un madero sobre uno de los indígenas, cosa que, dijo, en efecto sucedió. ${ }^{26}$

La predicción de sucesos constituye un aspecto esencial de la religión maya prehispánica; su arraigo entre los mayas coloniales se expresó en la amplia difusión que tuvieron los libros proféticos de Chilam Balam en los pueblos de la Gobernación de Yucatán.

Otro aspecto que nos permite asociar a K'at con el dios " $\mathrm{C}$ " se desprende de una ilustración de él en la página $8 \mathrm{c}$ del Códice de Dresde, donde aparece como un mono-duende profeta. Thompson señala al respecto:

\footnotetext{
24 "Autos que remite...", doc. cit.

${ }^{25}$ Diccionario maya Cordemex, dir. Alfredo Barrera Vásquez, Ediciones Cordemex, Mérida, Yucatán, 1980.

26 "Autos que remite...", doc. cit.
} 
Dentro del primer templo está una figura diminuta del enigmático Dios C, a quien por mucho tiempo se le llamó dios mono debido a su hocico prominente. Por pasajes del Chilam Balam de Tizimín y de Maníse sabe que el chilam entraba en una pequeña habitación, presumiblemente en un templo, a tomar la profecía (del katún). Permanecía con la boca en tierra, sin moverse... para oír la profecía comunicada por una figura como de duende, subida en las vigas o en el caballete del techo, llamada max, mono araña, término que por extensión incluía a los duendes. ${ }^{27}$

Quizá la toponimia del lugar donde se realizó el culto, atestiguado por De la Sosa, Pech Max [Pech Maax], literalmente mono-aplastado [¿sacrificado?], sea relevante, pues pudo significar el lugar donde se manifestaba ese duende-mono agorero entre los mayas insumisos de "Las Montañas".

Las prácticas de adivinación perviven hasta nuestros días en las comunidades indígenas mayas más conservadoras y resulta natural que dicha costumbre haya prevalecido entre los pueblos de "Las Montañas" durante el siglo xvII. La súplica de profecías a las deidades a través de las imágenes que las representaban fue una práctica habitual entre los montaraces; Villagutierre cita el caso de un indígena recién convertido que intentó realizar una rebelión en la congregación de Chichanhá [Chichanha'] ${ }^{28}$ "instigado por el demonio que le hablaba en unos ídolos que había escondido en el monte". ${ }^{29}$

Por otra parte, De la Sosa señaló que una noche, en el curso de una ceremonia y estando embriagado, Antón K'u le perforó el septum o ternilla de la nariz; tal horadación tuvo el propósito de insertarle ahí un ramillete..$^{30}$ El documento asienta que los montaraces eran reconocidos "por la insignia de traer abierta la ternilla de las narices, como lo estilan de continuo dichos indios." ${ }^{11}$

La perforación de la nariz era una costumbre muy difundida entre los pueblos montaraces; Villa Rojas menciona que los cehaches se horaban la nariz para colocarse una "vainilla olorosa"; ${ }^{2}$ en este caso,

${ }^{27} \mathrm{~J}$. Eric S. Thompson, Un comentario al Códice de Dresde, Fondo de Cultura Económica, México, 1988, p. 105.

28 "Lugar de agua pequeña".

${ }^{29}$ Juan de Villagutierre y Sotomayor, Historia de la conquista de Itzá, Ed. de Jesús M. Garciás, Historia 16, Madrid, 1985. (Crónicas de América, 13); pp. 312-313.

30 "Autos que remite...", doc. cit.

31 "Autos que remite...", doc. cit.

${ }^{32}$ Alfonso Villa Rojas, "Los Quejaches: una tribu olvidada del antiguo Yucatán", en Estudios etnológicos: los mayas, Instituto de Investigaciones Antropologicas, UNAM, México (Serie Antropologica, 38), p. 461. 
por las palabras del proceso, parece que De la Sosa traía flores, quizá puede tratarse del pericón, planta de olor agradable que causa bienestar general a quien la aspira. Esta costumbre es de origen prehispánico; Landa refiere que los mayas de Yucatán "eran amigos de buenos olores y por eso usan remilletes de flores y yerbas olorosas, muy curiosos y labrados". 33

Además de los cultos montaraces, el documento contiene indicaciones acerca de las operaciones militares que la Gobernación llevó a cabo en 1679, con el propósito de reducir las aldeas de "Las Montañas".

De la Sosa mencionó que transitó por la región acompañado por uno de los indígenas, del cual se separó una noche a causa de haber escuchado un disparo. Su afirmación cobra visos de credibilidad si consideramos que en 1679 la Gobernación realizó entradas militares en "Las Montañas", que culminaron con la destrucción de Thub (Nohthub) y Tzuctok, ${ }^{34}$ dos importantes aldeas de indios insumisos ubicadas en el sur de Cauich [Ka'wich], precisamente en la zona que De la Sosa recorrió. El conductor de esas entradas fue el capitán Alonso García de Paredes, quien entonces ganaba los méritos que le valieron obtener el mando de la expedición al Petén Itzá, realizada 16 años después. Este personaje es mencionado en distintos pasajes del documento; De la Sosa afirmó que dicho capitán había sacado de "Las Montañas" a Antón K'u, que al parecer fue confinado a trabajar en la estancia de Nohakal [Nohak'al]. Luis Che, el colector de cera que guió a De la Sosa, afirmó que para penetrar en "Las Montañas" intentó obtener el permiso de García de Paredes, porque él representaba la mayor autoridad militar en la zona; sin embargo, al no localizarlo en la villa de Campeche obtuvo la venia de un capitán llamado Juan de Solís. Che también refirió que, viniendo de regreso a la Gobernación, observó que dos tropas indígenas, una de Cauich [Ka'wich] y otra de Bolonchén [Bolonch'een] de Caiuch [Ka'wich], se dirigían al interior de la región, llevando un mandamiento para que sus habitantes se entregasen. Resulta interesante añadir que el propio Luis Che había vivido en "Las Montañas" hasta abril o mayo de 1679, cuando él y otros 20 indios abandonaron la región y se entregaron al capitán Alonso García de Paredes.

La situación en "Las Montañas" era muy conflictiva en 1679, pues muestra la desintegración de las aldeas montaraces en un proceso rápido y violento. Es probable que el grupo asentado en el paraje de Pech Max

${ }^{33}$ Fray Diego de Landa, Relación de las cosas de Yucatán, Porrrúa, México, 1966, p. 35.

${ }^{34}$ Villagutierre, Historia..., pp. 290-291; Scholes y Roys, The Maya Chontal..., pp. 310311. 
[Pech Maax] haya sido parte de un poblado mayor, abandonado a raíz de las incursiones militares. Puede ser significativo que los mayas de Pech Max [Pech Maax] estuvieran ostensiblemente preocupados por saber "si les habría de sobrevenir algún mal", ${ }^{35}$ como lo asienta el documento; esta inquietud fue originada por la amenaza que representaban los soldados españoles en la región. El testimonio de Juan de la Sosa constituye una mirada breve, pero reveladora, sobre la adversa situación que padecían los pueblos de "Las Montañas" en 1679.

Por otra parte, el caso de Juan de la Sosa es por sí mismo excepcional: se trata de un individuo joven, de origen español, pero privado de los beneficios estamentarios que usualmente le corresponderían dentro de la sociedad colonial; marginado de los centros urbanos, De la Sosa estaba confinado en la estancia de Nohakal [Nohak'al], de la que terminó por fugarse, a causa de estar "cansado del tabajo" ${ }^{36}$ Esa parece ser una razón creíble de su huida, no así su versión de que fue engañado por los indígenas que le prometieron ir solamente de cacería, pues bien pudo regresar a la estancia cuando notó que se alejaba de ella más de lo prudente. Es difícil saber lo que sucedía en su fuero interno cuando aceptó marcharse con los indios, pero quizá lo sedujo la idea de encontrar en "Las Montañas" la libertad y opciones que le vedaban los estre-

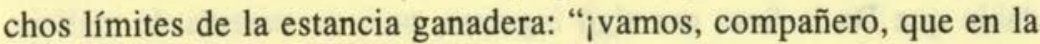
montaña hay pavas, jabalíes ... y otros muchos regalos...!", ${ }^{37}$ le dijo Antón Habnal [Haabnaal], y De la Sosa consideró que debía aprovechar tan halagüeña perspectiva.

El rechazo de Sosa a la sociedad española también tuvo razones de índole cultural: era un individuo desvinculado del mundo occidental, pues no sabía leer ni escribir y había olvidado su lengua materna, el español, y había adoptado la maya, resultado indudable de una larga y estrecha convivencia con los indígenas. Su fe católica era incluso bastante dudosa, pues también llegó a señalar que huyó por aversión a las confesiones de la Cuaresma. Rechazo a la religión católica y cansancio del trabajo eran razones que cualquier indígena montaraz habría esgrimido para justificar su fuga hacia las tierras insumisas del sur.

Al regresar a la Gobernación, el enfrentamiento de De la Sosa con la autoridad española resultó inevitable: el 9 de septiembre de 1679, apenas llegado a Cauich [Ka'wich], llamó la atención de Rebolledo, por traer perforada la ternilla nasal, rasgo que lo identificó como mon-

35 "Autos que remite...", doc. cit.

${ }^{36} \mathrm{Ibidem}$.

${ }^{37}$ Ibidem. 
taraz. Esto dio origen al primer documento del legajo, la orden de aprehensión contra Juan de la Sosa (documento II). Con intérprete de por medio, Sosa fue interrogado y comenzaron a conocerse sus andanzas. Esta primera declaración (documento III) tiene la misma fecha que la orden de aprehensión. Al aclarar el asunto, Rebolledo llamó a Luis Che para que rindiera su declaración, testimonio que constituye el documento IV. Al parecer el caso revistió cierta gravedad, pues el criollo fue enviado inmediatamente a Hopelchén [Hop'elch'een] y de allí a Mérida. Los custodios de Sosa llevaron una carta para don Antonio de Layseca, gobernador y capitán general de Yucatán, en la que Rebolledo le recomendó tomar conocimiento de los hechos (documento V). El 22 de septiembre, Layseca dio instrucciones para iniciar el proceso civil y ordenó se tomara una nueva declaración a Juan de la Sosa (documento VI). La diligencia se efectuó ese mismo día y fue conducida por el propio gobernador. En esta segunda declaración se traduce el pasmo de Layseca, visiblemente sorprendido por las confesiones del criollo montaraz (documento VII). Quizá conmovido por el caso, el gobernador asentó que el procesado le parecía "falto e incapaz", es decir, de escasa inteligencia y poco tino para regir sus actos, atenuante que resultaría decisiva para salvarlo de la prisión. Es indudable que De la Sosa era algo ingenuo, pero no carecía de malicia, pues intentó engañar a la autoridad cuando afirmó que sólo había estado siete días en Pech Max [Pech Maax], para después confesar que su estancia había durado seis semanas. Al confrontar sus declaraciones, se puede observar que De la Sosa se mostró sincero y decidió no mentir más. De hecho, no parecía consciente de lo comprometedor que resultaban sus afirmaciones. Tampoco imaginó que ellas habrían de acarrearle un segundo juicio, esta vez por parte del celoso defensor de la fe católica, el Tribunal del Santo Oficio de la Inquisición.

El 30 de septiembre, Layseca turnó el caso al comisario inquisitorial de Yucatán, Nicolás de Salazar, y ordenó que Sosa permaneciera en la real cárcel hasta en tanto el comisario no determinara su liberación (documento VIII). La disposición del gobernador fue notificada a Thomé de Lara, alcaide de la real cárcel, ese mismo día (documento IX).

El 3 de octubre, Francisco de Ávila, secretario mayor de la Gobernación, efectuó el testimonio de autos del proceso (documento X). El 9 de noviembre, Antonio de Villazís, notario del Santo Oficio, sacó un traslado y respaldó su autenticidad por medio de una fe notarial (documento XI). 
Después de considerar el caso durante una semana, Nicolás de Salazar determinó que lo conducente era informar y pedir un veredicto al Tribunal de la Inquisición de México. Con este propósito, el 17 de noviembre de 1679, envió el legajo y una carta en la que describió brevemente el asunto (documento I). Los papeles fueron recibidos en la capital novohispana el 16 de enero de 1680 . Pasaron casi cuatro meses sin que el Santo Tribunal diera una respuesta. Quizá temiendo un olvido por su parte, Salazar envió una carta el 30 de abril (documento XII), junto con otro traslado de los autos y declaraciones. Es por esta razón que en el legajo los interrogatorios están duplicados. Para esta edición sólo hemos considerado uno de los traslados, ya que ambos contienen la misma información. Esta misiva tuvo efecto, pues el 30 de mayo de 1680 el licenciado Joseph de Omaña Pardo, inquisidor fiscal de la Nueva España, dictó sentencia de liberación "ad cautelam" en beneficio de Juan de la Sosa (documento XIII). Las razones que llevaron a determinar esa decisión fueron: que los autos emanados de la causa civil no eran dignos de crédito para el Santo Oficio, dado que el gobernador de Yucatán no era juez competente, y que Juan de la Sosa era un individuo incapaz para regir sus actos, además de que había sido engañado por los indígenas. El veredicto fue enviado al comisario de Mérida el día 17 de junio. No sabemos cuándo lo recibió Salazar, pero éste liberó al preso, no sin antes cumplir con la formalidad de preguntarle sobre la doctrina cristiana y hacerlo decir las "cuatro oraciones", que el criollo recitó de manera poco satisfactoria. El 9 de diciembre de 1680, Salazar mandó una carta al Santo Oficio de México comunicando la liberación del prisionero. La carta fue recibida el 3 de mayo de 1681 (documento XIV).

De esta manera el caso quedó concluido y la aventura de Sosa tuvo un desenlace afortunado. Los documentos quedaron archivados en un polvoso volumen inquisitorial, e ignorados hasta hoy.

Tres siglos después, las revelaciones del criollo vagabundo nos permiten iluminar un poco las vicisitudes de aquellos grupos mayas que sufrieron los embates de las armas españolas a fines del siglo XVII, aquellos que en vano intentaron continuar viviendo bajo las normas culturales prehispánicas en sus recónditas aldeas de "Las Montañas" y que aún recurrían a sus antiguas deidades pidiéndoles orientación en una lucha que estaban destinados a perder irremediablemente. 
Mérida de Yucatán

\author{
CARÁTULA \\ [Cruz estilizada]
}

Autos que remite el Comisario de Campeche

contra

Juan de Sosa, español, natural del puerto de Campeche ${ }^{38}$

\title{
DOCUMENTO I
}

Acuse de recibo

Recibida en el Santo Oficio de

México, en diez y seis de enero

de seiscientos y ochenta años,

estando solo, en Audiencia de la

Año de 1679

mañana, el señor Inquisidor licenciado

Don Juan Gómez de Mier [rúbrica]

Consulta del Inquisidor de Mérida al Santo Oficio de México

17 de noviembre de 1679

Muy ilustres señores

Habiendo salido de Las Montañas de esta provincia, donde habitan cantidad de indios idólatras, Juan de Sosa, español, natural de la villa y puerto de Campeche, parece que la Justicia Real, reconociendo[le] venir de dicha montañas por la insignia de traer abierta la ternilla de las narices, como lo estilan de continuo dichos indios, hizo algunas diligencias judiciales. $\mathrm{Y}$ reconociendo tocar el conocimiento de la causa al Santo Oficio, me remitió testimonio de ellas, del cual hice sacar testimonio, que con esta remito a Vuestra Señoría para que disponga lo que más convenga al servicio de Dios Nuestro Señor y al Recto y Justificado Proceder del Santo Tribunal, que obedeceré con el desvelo de súbdito.

Parece que el sujeto es algo incapaz, según he sido informado y por los Autos consta. Queda por orden de la Real Justicia en prisión, como yo esperando las órdenes de Vuestra Señoría, a quien guarde Dios muchos años.

Mérida de Yucatán, 17 de noviembre de 1679 años.

\section{Ilustrísimos Señores}

Besa las manos de Vuestra Señoría, su más rendido súbdito.

Dr. Don Nicolás de Salazar

${ }^{38}$ Cf. nota 1. 


\section{DOCUMENTO II}

\section{Cabeza de Autos}

Testimonio de encarcelamiento de Juan de la Sosa

9 de septiembre de 1679

En el pueblo de Cauich [Ka'wich] en nueve días del mes de septiembre de mil y seiscientos y setenta y nueve años, yo, Martín de Rebolledo digo que Esteban Tzuc, ${ }^{39}$ Teniente de este dicho pueblo, me acaba de dar noticia como tiene en su casa un español que vino de "La Montaña" en compañía de un indio llamado Luis Che y para que se sepa quien es, mande al dicho Teniente lo pusiese en la cárcel con prisiones, con toda buena guardia y custodia, para que estando en ella recibirle su declaración y proveer lo que convenga.

Y lo firmé:

Martín de Rebolledo

\section{DOCUMENTO III}

\section{Primera declaración}

$\mathrm{Y}$ luego, in continenti [inmediatamente] hice traer a mi presencia al dicho español arriba contenido que, habiéndole hablado extrajudicialmente, reconocí que para poderle examinar es necesario hacerlo con intérprete, a causa que en la lengua castellana está muy torpe. Y para ello nombro por dicho intérprete al Alférez Baltazar de la Escalera, que sabe y entiende la lengua natural de esta provincia. Y estando presente aceptó y juró su buen uso. Y en virtud de dicho intérprete fue recibido juramento el dicho español, que lo hizo por Dios y una cruz, en forma de derecho, so cargo del cual prometió de decir verdad. $\mathrm{Y}$ habiéndosele hecho las preguntas que irán declaradas, dijo lo siguiente:

Fuéle preguntado que cómo se llama, de adónde es natural, que edad y oficio tiene.

Dijo que se llama Juan de las Sosas y que es natural de la Villa de Campeche, y que no es casado, y que es vaquero. No supo dar razón de su edad. Será, al parecer, de veinte y cinco años, poco más o menos.

Fuéle preguntado que cómo siendo natural de Campeche y español, al parecer estaba en "La Montaña" entre los indios cimarrones. Que cuánto ha que fue a ellas, qué causa o motivo tuvo para ello.

Dijo que ha tiempo de seis meses, que siendo este declarante vaquero de la estancia de Nicolás Sánchez, nombrada Nohakal [Nohak'al], un indio nombrado fulano $\mathrm{Ku}$ [K'u], que es uno de los que trajo Alonso García de "La Montaña", este tal, a este declarante y a otro indio del pueblo de Pocyaxam [Pok'yaxum],

39 "Estómago". 
que no sabe como se llama, por huir de las confesiones de la Cuaresma, los invitó a que fuesen con él, como lo hicieron, sin que nadie los viese. Y pasaron por el pueblo de Bolonchén [Bolonch'een] de Cauich [Ka'wich] un día, a la oración.

Fuéle preguntado que cómo dice que no ha más de seis meses que está en "La Montaña", siendo así que tiene agujereadas las narices, señal de los indios montaraces idólatras.

Dijo que a las cuatro semanas de su fuga a "La Montaña", una noche, este declarante y los dos indios que iban con él, bebieron balché ${ }^{40}$ y sacrificaron a un ídolo pequeño a quien encendieron algunas candelillas. Y estando embriagados de dicho balché, él y los dos indios, le horadaron las narices. Y cuando volvió en sí se halló de aquella suerte y prosiguieron su viaje por "La Montaña" sin llegar a ranchería ninguna, en cuyo tiempo, una noche, uno de los dichos dos indios que iban con él se les desapareció. Y días después oyeron un golpe que les pareció tiro, y con ello se pusieron en huida este declarante y el indio que había quedado con él, cada uno por su parte, y hallándose solo, rompió el arco y las flechas que llevaba y se volvió a buscar poblado, $\mathrm{Y}$ al cabo de cuatro días, llego este declarante a la ranchería de Jalalmis [Halalmis] de vuelta para acá, y lo halló despoblado, las casas cubiertas de hierba. Y hallando unas mazorcas de maíz viejas, se vino por el camino que hallo abierto, y en el camino encontró con tres indios y una india que traían dos caballos con cera, y llegaron a este pueblo.

Y esto que lleva dicho dijo ser la verdad por el juramento que lleva hecho en que se afirmó y ratifić́ siéndole dado a entender por dicho intérprete que lo firmó conmigo y el declarante no lo hizo porque dijo no saber.

Martín de Rebolledo

Baltasar de la Escalera

\section{DOCUMENTO IV}

\section{Testimonio de Luis Che}

Y luego, in continenti [inmediatamente], hice parecer ante mí a un indio que dijo llamarse Luis Che, del cual, mediante dicho intérprete fue recibido juramente, que lo hizo en forma de derecho, so cargo del cual prometio decir verdad.

Y siendo preguntado, dijo que habrá tres o cuatro meses que salió de "La Montaña" en compañía de veinte indios a este pueblo de Cauich [Ka'wich] y fueron a Campeche este declarante y algunos de sus compañeros a manifestarse a Alonso García, y por no hallarle en dicha villa, hablaron con el Capitán Don Juan de Solís a quien este declarante le pidió licencia para volver a "La Montaña", a traer una poca de cera que tenía allá y fue al pueblo de Bekal de donde es natural y llevó un hermano suyo con dos caballos y un su criado y pasaron por este pueblo y pidieron licencia al teniente de él y paso a la montaña donde tenía su cera y, viniendo de vuelta en el camino hallaron al español que está preso y se vinieron con él al pueblo de que dió cuenta a dicho Subteniente y se lo entrego.

40 "Cosa de madera". 
Y que [a] dos jornadas de este pueblo para la montaña, encontró este declarante dos tropas que serían por todos diez y seis de este pueblo y del de Bolonchén [Bolonch'een], y le dijeron [que] llevaba un Mandamiento o Carta para que los que están en la "La Montaña" se viniesen a entregar.

$\mathrm{Y}$ que esto que lleva dicho dijo ser la verdad por el juramento que lleva hecho, en que se afirmó y ratificó siéndole dado a entender.

No firmó porque dijo no saber, no supo dar razón de su edad, será, al parecer, de cuarenta años.

Y lo firmé con el intérprete,

Martín de Rebolledo

Baltasar de la Escalera

\section{DOCUMENTO V}

Envío de Juan de la Sosa al Señor Gobernador

9 de septiembre de 1679

En el dicho pueblo de Cauich [Ka'wich]] y en el dicho día, mes y año arriba contenido, yo Martín de Rebolledo habiendo visto estas declaraciones digo que se remitan con el preso al Sr. Gobernador y Capitán General de estas provincias para que en su vista, proveé y mande lo que fuere servido.

Y lo firmé

Martín de Rebolledo

\section{DOCUMENTO VI}

Mandamiento del señor Gobernador

22 de septiembre de 1679

Auto

En la ciudad de Mérida, en veinte y dos días de el mes de septiembre de mil seiscientos setenta y nueve años, el Señor General Don Antonio de Layseca Alvarado, Caballero del orden de Santiago, Gobernador y Capitán General de estas provincias de Yucatán por Su Majestad dijo:

Que por cuanto acaba de llegar a esta ciudad un hombre al parecer español, remitido desde el pueblo de Hopelchén [Hop'elch'een] por Martín de Rebolledo, el cual en cierta diligencia que hizo, y Su Señoría mandó se pongan por cabeza de estos Autos, parece ser montaraz, recién salido de "La Montaña" y aunque se tomó la declaración al susodicho conviene que se vuelva a tomar nuevamente declaración por preguntas y repreguntas mediante uno de los intérpretes generales, por cuanto parece habla más bien la lengua maya que la castellana para lo cual sea traído ante su señoría de la real cárcel donde está preso. 
Así lo proveyó y firmó

Ante mí

Layseca

Francisco de Avila

DOCUMENTO VII

Segunda Declaración de Juan de la Sosa

22 de septiembre de 1679

Y luego in continenti [inmediatamente], Su Señoría dicho Señor Gobernador y Capital General, hizo traer a su presencia al hombre contenido en estos Autos, y estándolo, por ante mí, el Escribano Mayor de Gobierno y Guerra y mediante lengua del Alfarez Luis Cardenia, Intérprete General fue recibido juramento y lo hizo por Dios y una cruz según forma de derecho y prometió de decir verdad y le fueron hechas las preguntas y repreguntas siguientes:

Preguntado por su nombre, edad, oficio, estado y naturaleza.

Dijo llamarse Juan de la Sosa y ser natural de la villa de Campeche, hijo del mismo ya difunto y de Nicolasa García, vecina de dicha villa. No supo decir su edad, por su aspecto, parece de veinte y cuatro años poco, más o menos, que es soltero y que no tiene oficio y esto responde:

Preguntado quien lo envió a esta ciudad, desde donde y porque causa lo prendieron, dijo que Martín de Rebolledo lo envió a esta ciudad y lo prendió en el pueblo de Hopelchén [Hop'elch'een] porque salió de "La Montaña".

Preguntado de que montaña salió, cuanto tiempo ha estado en ella, por que causa fue, quien lo envió y en que se ejercitó. Dijo que salió de "La Montaña" de Pechmex [Pech Maax] y que porque no le hagan extorsión, declara la verdad que ha estado en dicha montaña medio año, y que lo que pasa es que este declarante estaba en la estancia de Nohakal [Nohak'al] que compró el Capitán Nicolás Sánchez a Doña Isabel Beleño, y que el ganado que tenía dicho Nicolás Sánchez en otra estancia suya llamada Yaxcabalkal lo pasó a la de Nohakal [Nohak'al], donde este declarante era baquero. Y hallándose ya cansado del trabajo, un indio llamado fulano Ku [K'u] natural del pueblo de Pokyaxum, y su amiga, que no sabe como se llama, y otro indio llamado Anton Habnal [Haabnaal], que sirvió de Fiscal en Yaxcabalkal ${ }^{41}$ y después fue noriero de Nohakal [Nohak'al], le engañaron a este declarante para que con ellos se fuera a "La Montaña" diciéndole: ¡vamos, compañero, que en "La Montaña" hay pavas, jabalíes que llaman quitamez [kitamoob] y otros muchos regalos!, con que se hubo de ir con ellos al monte a hacer noche sobre el pueblo de Tixmucuy [Tix mukuy]. Y de ahí fueron por el monte a Sahcabchén, [Sah kab ch'een] y que de ahí lo fueron llevando por un camino ancho, sin que supiese los nombres de los parajes hasta que llegó al de Pechmax [Pech Maax] en el

41 "El primer pueblo bajo". 
cual hay, según la cuenta que hizo en las de un rosario, nueve indios de armas, seis indias y cuatro criaturas, donde estuvo siete días.

$\mathrm{Y}$ habiéndose hecho cierta pregunta confesó haber estado seis semanas y que el entretenimiento que tenían era de beber balche, género con que se embriagan para idolatrar compuesto de ciertas cáscaras de palo a falsos dioses. Que el uno de los que tenían en dicho paraje era una piedra pequeña negra a quien llamaban Sactum [Saktun] y otro a quien daban por título dios padre, y a quien adoraban llamado Kat [K'at], hecho de barro, como de seis dedos de alto, sin cabeza, más que sólo cuerpo, y que en los pechos tenía una cabeza con sus orejas y ojos, y que la dicha figura y piedra las ponían en el suelo y bailaban alrededor bebiendo el dicho balché, $\mathrm{y}$ este declarante entre ellos. Y que el sacerdote que asistía a estas funciones y hablaba con dicha figura era el dicho Antón Ku [K'u], del dicho pueblo de Pokyaxum [Pok' yaxum] que engañó a este declarante, gordo de cuerpo. Y que el haber idolatrado este declarante, fue de miedo de los indios, y solamente bailo con ellos y bebió dicho balche' y que se embriagó las veces que bailaron, no más. Y que los dichos indios se ponían a adivinar si les había de sobrevenir algún daño, y que sólo adivinaron que se les había de caer un palo en la cabeza como en efecto se cayó y sólo cogió a uno y lo lastimó. Y que la dicha figura nunca respondió nada de lo que le preguntaba el dicho Antón Ku [K'u] sacerdote. Y que un día por la mañana, estando este declarante embriagado, el dicho indio sacerdote le dijo "ven acá, te abriré esa nariz", y este declarante, de miedo de que no le sucediese algún trabajo, se consintió. Y con un pedernal le abujerearon [agujerearon] la nariz por dentro de la ternilla, por la parte interior o inferior de ella como lo demuestran las dichas sus narices, y que el tenerlas abujereadas [agujereadas] era para traer un ramillete en ellas.

Y que desde el dicho sitio de Pechmax [Pech Maax] se huyó este declarante, y al cabo de dos días topó en Yakab balam [Yak'ab Balam] [con] cuatro indios y una india del pueblo de Bekal, con dos caballos en que traían cuatro marquetas de cera. Y habiendo llegado al cabo de nueve días al pueblo de Cauich [Ka'wich], el dicho Martín de Rebolledo compró dichas marquetas de cera, y que sólo a este declarante prendió.

$\mathrm{Y}$ que los dichos indios de [Becal], queriendo venir a su pueblo y de ahí a esta ciudad con sus justicias, a dar noticia al Señor Gobernador como dicho Martín de Rebolledo les había comprado contra su voluntad la cera que traían para sus limosnas y otras cargas de dicho su pueblo, no consintó viniesen.

$\mathrm{Y}$ que esto es todo lo que ha pasado, sabe y la verdad de todo cuanto se le ha preguntado.

Aunque en diferentes preguntas y repreguntas, según sus respuestas y modo y acciones parece ser falto e incapaz, que para que conste, se pone por diligencia.

Y so cargo del juramento que tiene hecho, dijo ser la verdad, hijo de padres españoles no firmó porque dijo no saber.

Firmóla su Señoría con dicho intérprete y mandó sea vuelto a su prisión. Layseca

Luis Cardenia

Ante mí

Francisco de Avila 


\section{DOCUMENTO VIII}

El Gobernador de Yucatán al Comisario de la Inquisición de Mérida

30 de septiembre de 1679

En la ciudad de Mérida de Yucatán en treinta días del mes de septiembre de mil y seiscientos y setenta y nueve años, el señor General Don Antonio de Layseca Alvarado, Caballero del orden de Santiago, Gobernador y Capitán General de estas provincias de Yucatán por Su Majestad, habiendo visto estos Autos y la declaración hecha por Juan de la Sosa preso en la Real cárcel de esta dicha ciudad. Su Señoría dijo que por lo que mira o mirar puede en cualquiera manera contra nuestra Santa Fe Católica, el delito cometido por el susodicho (sin embargo de la incapacidad que demuestra tener) se lleve testimonio de estos autos al Señor Doctor Don Nicolás de Salazar, Racionero de la Santa Iglesia Catedral de esta ciudad y Comisario del Santa Oficio en ella, para el efecto que hallare ser más conveniente.

Y se lo notifiqué a Thomé de Lara Alcaide de la Real cárcel de esta ciudad, tenga preso en ella al dicho Juan de la Sosa y no le suelte sin primero dar cuenta a su señoría.

\section{Así lo proveyó y firmó Layseca, ante mí}

Francisco de Avila

\section{DOCUMENTO IX}

Aviso al Alcaide de la Real cárcel

\section{Notificación}

30 de septiembre de 1679

En la ciudad de Mérida de Yucatán, en el dicho día, mes y año dichos, yo el Escribano Mayor de Gobierno notifiqué el auto de atrás y arriba contenido por lo que le toca a Thomé de Lara, Alcaide de la Real cárcel de esta ciudad, en su persona, dijo que lo oye y cumplirá con lo que se le manda.

De ello, doy fe

Francisco de Avila

\section{DOCUMENTO X}

Testimonio de Autos

3 de octubre de 1670

Concuerda este traslado con los Autos y declaraciones originales de que va hecha mención, y quedan en la Secretaría Mayor de mi cargo a que me refiero. Y va cierto y verdadero, escrito en cinco fojas con ésta, el primero pliego en papel de sello cuarto, por ser de oficio, y lo demás, común. 
Y lo hice sacar, y saqué de mandato del Señor Gobernador y Capitán General de estas provincias, que es hecho en esta ciudad de Mérida, en tres días del mes de octubre de mil y seiscientos y setenta y nueve años.

Yo, Francisco de Avila, Secretario Mayor de la Gobernación y Guerra de estas provincias de Yucatán, Cozumel y Tabasco, por el Rey nuestro Señor, la hice sacar y en fe de ello hago mi signo, en testimonio de verdad.

Francisco de Avila

Enmendado: oier [sic], vala.

\section{DOCUMENTO XI}

Fe notarial

9 de noviembre de 1679

Concuerda este translado con los Autos y declaraciones del testimonio de que va hecho mención que remitio el señor General Don Antonio de Layseca Alvarado, Caballero del Orden de Santiago, Gobernador y Capitán General de estas provincias de Yucatán [por] Su Majestad, al Señor Doctor Don Nicolás de Salazar, Prebendado de la Santa Iglesia Catedral de esta ciudad y Comisario del Santo Oficio en ella.

Y lo saqué de mandato de dicho Señor Comisario. Y va cierto y verdadero, corregido y enmendado en cuatro fojas con esta, según dicho testimonio que queda en poder de dicho Señor Comisario a que me remito, que es hecho en esta ciudad de Mérida en nueve días del mes de noviembre de mil seiscientos y setenta y nueve años.

$\mathrm{Y}$ de ello doy fe, en testimonio de verdad

Licenciado Antonio de Villazis

[Rúbrica]

Notario del Santo Oficio

\section{DOCUMENTO XII}

Acuse de recibo en el Santo Oficio de México

31 de mayo de 1680

Recibida en el Santo Oficio de México, en treinta y uno de mayo de seiscientos y ochenta, estando en Audiencia de la mañana el Señor Inquisidor Licenciado Don Juan Gomez de Mier.

[Rúbrica] 
Carta del Comisario del Santo Oficio de Mérida al Santo Oficio de México

30 de abril de 1680

Muy Ilustres Señores

Nota

A la causa donde toca y la vea el Señor Inquisidor que hace oficio de Señor Fiscal.

[Rúbrica]

En días pasados remití al Santo Tribunal un testimonio sacado de él que me remitió el Gobernador y Capitán General de estas provincias, de la declaración y juramento que se le tomó a Juan de Sosa, español natural de la villa de Campeche, que vino de las montañas donde habitan cantidad de indios ind6mitos e idólatras, con la insignia que estilan dichos indios: abiertas las ternillas de las narices, quien por orden de la Real justicia está preso en la cárcel pública de esta ciudad; para que Vuestra Señoría me ordenase lo que al mayor servicio de Dios Nuestro Señor conviniere al Santo Tribunal.

En esta, remito el mismo testimonio que se me enví como al Ministro del Santo Oficio por dicha Real Justicia para que en su vista disponga Vuestra Señoría lo que más comvenga al recto y justificado proceder del Santo Tribunal, cuyas órdenes observare con el desvelo de rendido súbdito. Lo que puedo informar del contenido es que padece alguna incapacidad, según me he informado de personas fidedignas y parece por dicho testimonio.

Dios guarde a Vustra Señoría muchos años.

Mérida de Yucatán, treinta de abril de mil seiscientos ochenta años.

Ilustrísimos Señores

Besa las manos de Vuestra Señoría, su más obediente súbdito, Doctor Don Nicolás de Salazar

[Rúbrica]

\section{DOCUMENTO XIII}

\section{Acuse de recibo [Cruz estilizada]}

Presentada en el Santo Oficio de México

en el diez y siete de junio de seis

cientos ochenta, estando en audiencia

de la mañana el Señor Inquisidor

Licenciado Don Juan Gómez de Mier. 


\section{Carta del Santo Oficio de México}

al Comisario de Mérida

30 de mayo de 1680

El Señor Inquisidor que hace oficio de Fiscal, ha visto la carta del Comisario de Mérida de Yucatán de treinta de abril de este año, y el testimonio que con ella remite de los Autos que el Gobernador de dicha ciudad formaron contra Juan de Sosa, español natural del puerto de Campeche, por haber el susodicho estado en las montañas donde habitan los indios indómitos e idólatras, con la insignia que estilan dichos indios, abiertas las ternillas de las narices.

Y aunque ambos Autos no se debe estar, por ser hechos por juez incompetente de lo que dicho resulta es: que siendo el dicho Juan de Sosa vaquero de una estancia de Nicolás Sánchez, se dejó engañar de dos indios amigos suyos, los cuales le sacaron de dicha estancia diciéndole que en "Las Montañas" había muchos regalos y habiendo llegado a "Las Montañas" estuvo como seis meses con dichos indios bárbaros, quienes acostumbraban para idolatrar, beber una bebida que se embriaga con ella, que habiéndola tomado se embriagó y por efecto hizo algunas ceremonias en compañía de los dichos indios bárbaros. Por temor que no le hiciesen algún daño, con que por esto y dar al dicho Juan de Sosa incapaz según informa el dicho Comisario, y harán que esta causa no tiene substancia ni cuerpo para que se pueda proseguir en ella, y haciendo constar que por esto el susodicho esta preso, Vuestra Señoría, siendo servido, podrá mandar que el Comisario de Mérida tome al susodicho su declaración y reconozca si tiene algún error contra nuestra Santa Fe Católica y si sabe la doctrina cristiana, y [si] constándole al dicho Comisario que el dicho Juan de Sosa no tiene ningún error, y está firme en nuestra fe Católica y quiere permanecer en ella, le proceda a absolver ad cautelam [por previsión]. Y no estando preso [más] que por lo dicho, se le podrá soltar de la carcelería en que está.

Vuestra Señoría acordará lo que fuera servido con justicia que pide y para ello y remite se cumpla. Mayo 30 de 1680.

\section{Licenciado Joseph de Omaña Pardo, Inquisidor}

[Rúbrica]

$\mathrm{Y}$ vistos en dicho día, mes y año por dicho Inquisidor estando en dicha audiencia dijo que debía de mandar y mandó se haga despacho al Comisario de Mérida de Yucatán en conformidad de lo que el señor Inquisidor Fiscal dice en su escrito inmediato antecedente y así lo acordó mandó y firmó.

Juan Gómez de Mier

Pasó ante mi

$$
\begin{array}{r}
\text { de Mendizabal } \\
\text { Secretarío } \\
\text { [Rúbrica]. }
\end{array}
$$

En dicho día, mes y año se escribió carta por

duplicado al Comisario de Mérida Dr. Don Nicolás

de Salazar en conformidad de lo pedido por el señor 
Inquisidor Fiscal y su ejecusión del auto de arriba se registró a foja 12 del libro Jornadas y se remitió a dicho Comisario en puerto de la Veracruz.

[Rúbrica]

\section{DOCUMENTO XIV}

Acuse de recibo

Diciembre 9 de 1680

Recibida en el Santo Oficio de México en tres de marzo de mil y seiscentos y un año, estando en Audiencia de la mañana, el señor Inquisidor Licenciado Don Juan Gómez de Mier.

[Rúbrica]

A los Autos que hay contra este sujeto y tráiganse [Rúbrica]

Carta del Comisarío de Mérida al tribunal del Santo Oficio

Muy ilustres señores:

Luego que recibí la comisión que el Santo Tribunal de la Inquisición fue servido remitirme, su fecha del 17 de junio de este presente año, para tomar la declaración de Juan de Sosa, español natural de la villa y puerto de Campeche, a quien tenía preso la Real Justicia y procedido contra de él, cuyas diligencias. se remitieron como a Comisario del Santo Oficio, por pertenecer la causa al Santo Tribunal, hice parecer ante mí al susodicho, trayéndole de la Real Cárcel y tomé su declaración, de la cual no resultó error alguno, contra nuestra Santa fe Catolica, más que haber estado en "La Montaña" con unos indios, bebido el brebaje nomibrado balché, bebida que usan para sus idolatrías, bailado ante unos ídolos por demostración de culto, consintiendo se le abriesen las narices, todo por temor de dichos indios y por simpleza y poca capacidad del susodicho, que es lo mismo que resulta de las diligencias que ante la justicia Real se hicieron. Habiendo dicho antes las cuatro oraciones y respondido algunas preguntas que le hice de la doctrina cristiana, aunque algunas no dio razón por su ineptitud, le absolví ad cautelam, y dí por libre, enviando un recado con el Notario al Gobernador y Capitán General de estas provincias que le tenía preso, que por lo que tocaba al Santo Oficio, estaba libre el dicho Juan de Sosa y que podía ser suelto de la carcelería en que estaba. Doy parte a Vuestra Señorfa cumpliendo con el orden de dicha comisión y su mandato a que siempre 
estaré muy obediente, como súbdito que desea el desempeño de su obligación y pide a Dios Nuestro Señor dilate la vida de Vuestra Señoría a siglos y le de muchos años. Mérida de Yucatán, 9 de diciembre de 1680 años.

\section{Ilustrísimos señores}

Besa la mano de vuestra señoría, su más rendido súbdito, Doctor Don Nicolás de Salazar.

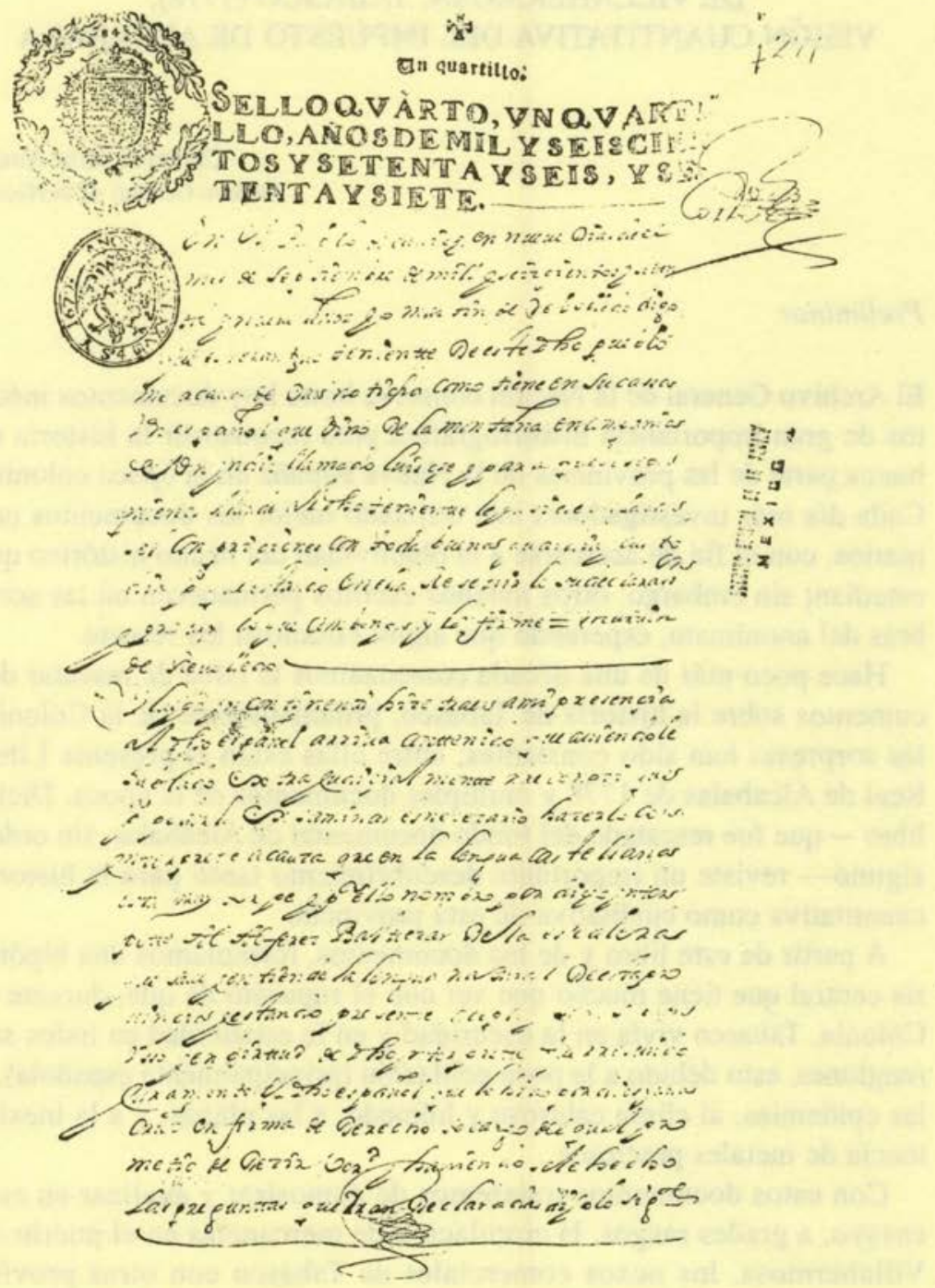

